\title{
RESEARCH ON THE ENTOMOFAUNA OF ORTHOPTERA IN SOME VEGETABLE CROPS IN SOUTHERN OLTENIA
}

\author{
Felicia-Oana Bîrzanu ${ }^{1 *}$, Ion Mitrea ${ }^{2}$ \\ ${ }^{1} \mathrm{PhD}$ University of Craiova, Craiova, Romania \\ ${ }^{2}$ University of Craiova, Faculty of Horticulture, Craiova, Romania
}

\begin{abstract}
Orthoptera comprise an order of common insects, most of which are phytophagous, but there are also predatory orthoptera. They are found all over the world and adapt to the environmental conditions in which they are found. Orthoptera insects are pests of vegetable plants, destroying large areas, so vegetable growers are familiar with them. The research was carried out in the Amărăștii de Jos stationary in 2020 in vegetable crops. The aim of the research was to identify orthoptera species in vegetable crops and two methods were used to collect them: the beer trap method and the Barber soil trap method). Orthopteran insects were identified with the help of specialized determiners, then classified by family down to species level. Orthoptera currently identified in the stationary studied included six species, namely: Gryllotalpa gryllotalpa, Gryllus campestris, Gryllus desertus, Acrida hungarica, Dociostaurus maroccanus and Calliptamus italicus. The species with the most specimens is Gryllotalpa gryllotalpa (42 specimens) and the species with the fewest specimens is Dociostaurus maroccanus (3 specimens).
\end{abstract}

Keywords: methods, orthoptera, pests, vegetables.

\section{INTRODUCTION}

Worldwide, many researchers have studied both beneficial and harmful entomofauna in vegetable crops, as well as measures to control them and the effects of insecticides on them.

Orthoptera have been known since ancient times, with the first comprehensive account being 35003700 years ago when the locust migration took place and the first information on the morphological description of orthopteran species was given by the Greek scholar Aristotle.

Worldwide, research on pest entomofauna in some vegetable crops has been carried out by: Baysal and Cinar (2007), Balliu and Cota (2007), Boucher Jude et all (2003).

In Romania, the first scientific considerations on the orthoptera fauna were provided by Carl Fuss $(1853,1855,1869)$ and referred to the orthopteran species around Sibiu.

The study of orthopterans in our country was dealt with by Burr (1899), Mîndru (1956), but also by Zottu. between 1903-1909, when he published four systematic lists of orthopterans in our country in Science Society Bulletin of Bucharest.

In Romania in 2008, there were 182 identified species of orthoptera, including 94 species of the order Ensifera and 88 species belonging to the order Caelifera.

There are 9 species of orthoptera that are endemic to our country, namely: Isophya dobrogensis, Isophya harzi, Callimenus montandoni, Odontopodisma carpathica, Odontopodisma acuminata, 
Odontopodisma montana, Zubovskya banatica, Posidmopsis transsylvanica and Chorthippus acroleucus. (Doiniță., 2005)

A new species has arisen in the Romanian fauna, namely Zeuneriana amplipennis, a cricket discovered in Cernavodă (Iorgu et al., 2008, 2012).

Every year, production losses caused by pests and pathogens amount to $25-30 \%$, maybe even more, often leading to crop failure.

In our country, research on the entomofauna found in vegetable species has been carried out by Roman and Neamțu (2007), Costache and Roman (2004), and in this region a scientific contribution was made by Bobîrnac B., Matei (1983), Mitrea et al. (2010).

The research was carried out in Dolj County, in the stationary of Amărăștii de Jos commune, a locality where vegetables are grown on large areas with rich crops.

Hence the importance of entomology and integrated control in vegetable growing.

With the introduction of new varieties of vegetables in the culture, in order to offer the most diverse assortments, the presence of some species of pests was also noted, pests that affect not only the foliar apparatus but also the fruits.

\section{MATERIALS AND METHODS}

The diversity of vegetable species also attracts a diversity of harmful insect species, especially if the environmental conditions are favourable, thus causing irreparable damage.

This paper has the role of bringing a contribution of scientific data obtained after conducting some research that refer to the entomofauna of orthoptera from some vegetable crops in southern Oltenia. Within the range of the locality Amărăștii de Jos - Dolj County, research was conducted in some vegetable crops, thus organizing 3 stationeries.

In 2020, two methods of collecting entomofauna were used (the Barber type soil trap method and the beer soil trap method).

For the beer soil trap, $0.5 \mathrm{ml}$ plastic bottles and a few millilitres of beer were needed, the bottle is cut at the top, i.e. the part with the cork, it is inserted with the neck down into the ground, the beer is poured and the trap is buried at ground level.

Beer is replaced every 5 days.

Sampling was done periodically, depending on the growing season of the crops but also on the research method.

The study included stationeries which comprised 6 traps in a row of plants from the edge inwards in a straight line, 20 metres from the edge and 6-8 metres between traps per row.

For the Barber method, $500 \mathrm{ml}$ plastic boxes, with a $10 \mathrm{~cm}$ diameter and $8 \mathrm{~cm}$ in height were used, and a salt solution with a concentration of $25 \%$ was used as a fixing liquid.

The entomofauna collected from the vegetable ecosystem was analyzed in detail regarding the systematic group to which each species belongs, with the help of specialized determinants.

Representatives were identified and sorted by family and order by species level.

\section{RESULTS AND DISCUSSION}

In 2020, the results obtained from some vegetable crops regarding the structure of the entomofauna of harmful orthoptera in southern Oltenia, included the identification of 6 harmful species (Fig. 1) belonging to the Insecta class, totalling a number of 67 specimens collected. 


\section{Current Trends in Natural Sciences}

Vol. 10, Issue 19, pp. 187-193, 2021

https://doi.org/10.47068/ctns.2021.v10i19.025

Current Trends in Natural Sciences (on-line)

\section{Species (\%)}

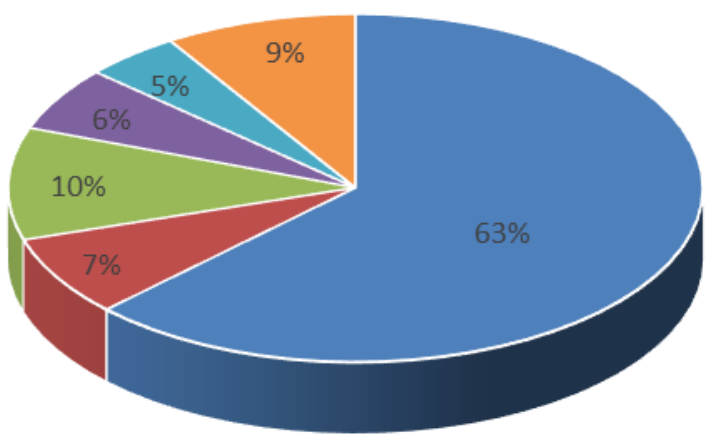

- Gryllotalpa

gryllotalpa

- Grylluscam pestris

- Gryllus desertus

- Acrida hungarica

- Dociostaurus

maroccanus

- Calliptamus italicus

Figure 1. Number of orthoptera species collected classified by families (Amărăștii de Jos Stationary - Dolj County)

Regarding the structure of the species collected by families, it is noted that most species belong to the family Acrididae (3 species), followed by the family Gryllidae with two species and the family Gryllotalpidae has only one species. (Table 1).

Table 1. The structure of the orthopteran entomofauna collected by families in some vegetable crops from the south of Oltenia (Amărăștii de Jos - Dolj Station)

\begin{tabular}{|c|c|c|c|c|}
\hline No. & Order & Family & The name of the species & Abundance \\
\hline 1. & Orthoptera & Gryllotalpidae & Gryllotalpa gryllotalpa & 42 \\
\hline 2. & & Gryllidae & Gryllus desertus & 7 \\
\hline 3. & & & Gryllus campestris & 5 \\
\hline 4. & & Acrididae & Calliptamus italicus & 6 \\
\hline 5. & & & Dociostaurus maroccanus & 3 \\
\hline 6. & & & Acrida hungarica & 4 \\
\hline
\end{tabular}

Analyzing the results on the abundance of harmful species collected from some vegetable crops, it is noted that the species Gryllotalpa gryllotalpa is the most numerous, with most specimens collected (42) followed by the species Gryllus desertus with 7 specimens, Calliptamus italicus (6 specimens), Gryllus campestris (5 specimens), Acrida hungarica (4 specimens), and on the last place there is Dociostaurus maroccanus with 3 specimens. (Table 1)

In order to understand the structure and dynamics of the collected entomofauna, it was subjected to mathematical analyzes using certain ecological indicators, indicators made according to the model created by Simionescu (1984).

Dominance (D) is considered an index of productivity, showing the percentage of participation of each species in achieving a biomass production in the biocenosis.

(Table 2). 
$\mathrm{DA}=\mathrm{nA}: \mathrm{NX100}$, where: DA represents the dominance of species $\mathrm{A}, \mathrm{nA}$ represents the total number of specimens from species $A$, which were found in research samples $N(N$ is the total number of specimens of the species that were present in the research sample).

Depending on the value of the percentage that expresses their individual dominance, the distribution of species takes place in the following classes: class D1 includes subrecedent species (i.e. below $1.1 \%$ ), class D2 has recedent species (between 1.1 and 2\%), class D3 includes subdominant species (between 2.1 and 5\%), class D4 has dominant species (between 5.1 and 10\%), and class D5 includes eudominant species with a percentage of over $10 \%$. (Table 2)

Table 2. Dominance of species collected by families

\begin{tabular}{|c|c|c|}
\hline Family & The name of the species & Dominance \\
\hline Gryllotalpidae & Gryllotalpa gryllotalpa & 62.68 \\
\hline Gryllidae & Gryllus campestris & 7.46 \\
\cline { 2 - 3 } & Gryllus desertus & 10.44 \\
\hline Acrididae & Acrida hungarica & 5.9 \\
\hline & Dociostaurus maroccanus & 4.47 \\
\hline & Calliptamus italicus & 8.95 \\
\hline
\end{tabular}

Table 2 shows that there are 5 recedent species and a dominant species Gryllotalpa gryllotalpa.

Constancy (C) represents a continuity in terms of the occurrence of a species in the biotope presented, showing the proportion of any species that participates in the realization of the structure of that biocenosis.

Constancy is estimated with the relationship: $\mathrm{CA}=\mathrm{npA}: \mathrm{Npx} 100$, where: $\mathrm{CA}$ is the constancy of species A;

npA is the number of samples in which species $\mathrm{A}$ is found;

$\mathrm{Np}$ - includes the final number of samples that were examined.

Regarding the value of this indicator, it was agreed to distribute the species as follows: Class C1 comprises accidental species and consists in between 1 and $25 \%$ of the samples taken, Class C2 comprises accessory species i.e. between 25.1 and $50 \%$ of the samples, Class C3 comprises constant species with a percentage between 50.1 and $75 \%$ of the samples, Class C4 comprises euconstant species which are in a percentage between 75.1 and $100 \%$ of the samples. (Table 3)

Table 3. The constancy of the species collected

\begin{tabular}{|c|c|c|c|}
\hline No. & Family & The name of the species & Constancy \\
\hline 1 & Gryllotalpidae & Gryllotalpa gryllotalpa & 77.77 \\
\hline 2 & Gryllidae & Gryllus campestris & 55.55 \\
\cline { 3 - 4 } & & Gryllus desertus & 66.66 \\
\hline 4 & Acrididae & Acrida hungarica & 55.55 \\
\hline 5 & & Dociostaurus maroccanus & 44.44 \\
\hline 6 & & Calliptamus italicus & 55.55 \\
\hline
\end{tabular}

There is an accessory species, namely Dociostaurus maroccanus and a euconstant species Gryllotalpa gryllotalpa, and the constant species are Gryllus campestris L, Gryllus desertus L, Acrida hungarica, Calliptamus italicus.

$\mathrm{W}$ is the ecological significance index 
It shows us the relationship between the productive indicator (D) and the structural indicator (C) and it is calculated by the relationship: $W=C_{s p} \times D_{s p} \times 100 / 10000$.

Species are classified according to the values of the $\mathrm{W}$ index as follows:

W1 comprises subrecedent species with values less than $0.1 \%$

W2 comprises recedent species with values between 0.1 and $1 \%$

W3 comprises subdominant species with values between 1.1 and 5\%

W4 includes the dominant species, species that are between 5.1 and $10 \%$ and the last W5 is an index with values higher than 10\%, having eudominant species (Table 4).

Table 4. Ecological index (W) values for collected species

\begin{tabular}{|r|c|c|c|}
\hline No. & Family & The name of the species & W \\
\hline 1 & Gryllotalpidae & Gryllotalpa gryllotalpa & 48,74 \\
\hline 2 & Gryllidae & Gryllus campestris & 4,14 \\
\cline { 3 - 4 } 3 & & Gryllus desertus & 1,07 \\
\hline 4 & Acrididae & Acrida hungarica & 6,95 \\
\hline 5 & & Dociostaurus maroccanus & 1,98 \\
\hline 6 & & Calliptamus italicus & 4,97 \\
\hline
\end{tabular}

W3 subdominant species: Gryllus campestris L, Gryllus desertus L, Dociostaurus maroccanus, Calliptamus italicus;

W4 dominated species: Acrida hungarica;

W5 eudominant species: Gryllotalpa gryllotalpa.

\section{CONCLUSIONS}

The importance of insects in human life and in nature is due to characteristics of internal and external structure that allow them to easily adapt to different environmental conditions.

Insects of the order Orthoptera represent a detachment of neoptera with an incomplete transformation, i.e. the larvae that hatch from eggs have the same appearance as adults, only much smaller.

Harmful entomofauna can serve as indicators for solving some problems, their frequency in certain ecosystems or why not as mathematical models of the dynamics of animals of economic interest.

The entomofauna of orthoptera identified so far in the stationary of Amărăștii de Jos, includes three families with six species.

The largest share is held by the species Gryllotalpa gryllotalpa - species with 42 specimens, belonging to the family Gryllotalpidae, with the species Dociostaurus maroccanus coming last with 3 specimens, a species belonging to the family Acrididae.

\section{REFERENCES}

Balliu, A., Cota, E. (2007). Biological control of main greenhouse pests in Albania. Acta Horticulture (Vol.729, pp.489492).

Baysal, F., Cinar A. (2007). Determination of phytopathological and entomological problems and using plant protection methods in organic tomato growing in Turkey. Acta Horticulture (Vol. 729, pp. 459-462).

Bobîrnac, B., Stănoiu, I., Năstase, A. (1994). Determinator pentru Coleopterele din România [Determinant for Coleoptera in Romania] (pag. 1- 49). City: Oltenia Museum, Craiova.

Bobîrnac, C., Matei, I., (1983). Contribuții la studiul entomofaunei unor culturi horticole din Oltenia [Contributions to the study of the entomofauna of some horticultural crops from Oltenia]. Lucr. Șt. A III Conf. Naț. Entomologie, Iași.

Boucher, J., Ashley, R., Durgy, R., Sciabarassi, M., Caldewood, W. (2003). Managing the pepper maggot (Diptera: Tephritidae) using perimeter trap cropping. Journal of Economic Entomology (Vol.96, no.2, pp.420-432). 
Burr, M. (1899). List of the Orthoptera of Romania, with localities. The Enthomologist's Monthly Magazine. Second series, 10, 88-91.

Costache, M., Roman, T. (2004). Combaterea agenților patogeni și a dăunătorilor în procesul producerii răsadurilor[Control of pathogens and pests in the process of seedling production]. Revista Horticultura[Horticulture Magazine], 4, 2-5.

Doniță, N., Popescu, A., Păucă-Comănescu, M., Mihăilescu, S., Biriși, A. (2005). Habitatele din România [Habitats in Romania] (pp.476). City: Forestry Technical Publishing House, Bucharesti.

Fuss, C. (1855). Beitrag zu Orthopterenfauna Siebenbürgers, Verh. Mitt. Sieben. Ver. Natur. Hermannstadtt [Contribution to the orthopter fauna of Transylvania, Verh. Mitt. Sieben. Ver. Nature. Sibiu]. 6, 21-23.

Fuss, C. (1853). Beitrag zur Orthopteren und Hemipterenfauna Siebenburgensis. Verh. Mitt. Sieben. Ver. Natur. Hermannstadtt [Contribution to the orthopter and hemipteran fauna of Siebenburgensis. Ratio average seven. Ver. Nature. Sibiu]. 4, 40-46.

Iorgu, I., Pisică, E., Păiș, L., Lupu, G., Iușan, C. (2008). Checklist of Romanian Orthoptera (Insecta) and Their Distribution by Eco Regions (Vol. 2, pp. 119-135). City: "Grigore Antipa" National Museum of Natural Sciences, Bucharest

Iorgu, I. (2012). Bioacoustics of Isophyta dobrogensis a Romanian endemic bush - cricket (Orthoptera). "Grigore Antipa" National Museum of Natural History, 44, 51-56.

Mîndru, C. (1956). Contribuții la cunoașterea ortopterelor din Dobrogea. Studii cercetare [Contributions to the knowledge of orthoptera in Dobrogea. Research studies], (pp. 291-297). City: Biology, Iași.

Mitrea, I., Stan, C., Țucă, O. 2010. Entomologie general [General entomology], City: Publishing House Reprograph, Craiova.

Roman, T. (2007). Unul dintre cei mai de temuţi dăunători ai răsadurilor de legume [One of the most feared pests of vegetable seedlings]. Plant Health Magazine, 2/93, 27.

Simionescu, V. (1983). Lucrări practice de ecologie [Practical works of ecology] (pp.192), City:,,A. I. Cuza” University, Iași.

Zottu, ST. (1903). Liste des Orthopteres recoltés en Roumanie [List of Orthoptera harvested in Romania], Bull. Soc. Sci. Bucharest, 12.

Zottu, ST. (1909). Quatrieme liste des Orthopteres de Roumanie [Fourth list of Romanian Orthoptera], Bull. Soc. Sci. Bucharest, 18, 39-42. 